\title{
Elucidation of the roles of adhE1 and $a d h E 2$ in the primary metabolism of Clostridium acetobutylicum by combining in-frame gene deletion and a quantitative system-scale approach
}

Minyeong Yoo ${ }^{1,2,3}$, Christian Croux ${ }^{1,2,3}$, Isabelle Meynial-Salles ${ }^{1,2,3}$ and Philippe Soucaille ${ }^{1,2,3,4^{*}}$

\begin{abstract}
Background: Clostridium acetobutylicum possesses two homologous adhE genes, adhE1 and adhE2, which have been proposed to be responsible for butanol production in solventogenic and alcohologenic cultures, respectively. To investigate their contributions in detail, in-frame deletion mutants of each gene were constructed and subjected to quantitative transcriptomic (mRNA molecules/cell) and fluxomic analyses in acidogenic, solventogenic, and alcohologenic chemostat cultures.

Results: Under solventogenesis, compared to the control strain, only $\triangle a d h E 1$ mutant exhibited significant changes showing decreased butanol production and transcriptional expression changes in numerous genes. In particular, adhE2 was over expressed (126-fold); thus, AdhE2 can partially replace AdhE1 for butanol production (more than $30 \%$ of the in vivo butanol flux) under solventogenesis. Under alcohologenesis, only $\triangle a d h E 2$ mutant exhibited striking changes in gene expression and metabolic fluxes, and butanol production was completely lost. Therefore, it was demonstrated that AdhE2 is essential for butanol production and thus metabolic fluxes were redirected toward butyrate formation. Under acidogenesis, metabolic fluxes were not significantly changed in both mutants except the complete loss of butanol formation in $\triangle a d h E 2$, but numerous changes in gene expression were observed. Furthermore, most of the significantly up- or down-regulated genes under this condition showed the same pattern of change in both mutants.

Conclusions: This quantitative system-scale analysis confirms the proposed roles of AdhE1 and AdhE2 in butanol formation that AdhE1 is the key enzyme under solventogenesis, whereas AdhE2 is the key enzyme for butanol formation under acidogenesis and alcohologenesis. Our study also highlights the metabolic flexibility of C. acetobutylicum to genetic alterations of its primary metabolism.
\end{abstract}

Keywords: AdhE, Butanol, Clostridium acetobutylicum, System-scale analysis

\section{Background}

Clostridium acetobutylicum is now considered as the model organism for the study of solventogenic Clostridia $[1,2]$. The superiority of butanol over ethanol as an

\footnotetext{
*Correspondence: philippe.soucaille@insa-toulouse.fr

${ }^{4}$ Metabolic Explorer, Biopôle Clermont-Limagne, Saint Beauzire, France Full list of author information is available at the end of the article
}

alternative biofuel has attracted research interest into $C$. acetobutylicum and other recombinant bacteria producing butanol as major products [3].

In phosphate-limited chemostat cultures, C. acetobutylicum can be maintained in three different stable metabolic states [4-8] without cellular differentiation [9]: acidogenic (producing acetate and butyrate) when grown at neutral $\mathrm{pH}$ with glucose; solventogenic (producing 
acetone, butanol, and ethanol) when grown at low $\mathrm{pH}$ with glucose; and alcohologenic (forming butanol and ethanol but not acetone) when grown at neutral $\mathrm{pH}$ under conditions of high $\mathrm{NAD}(\mathrm{P}) \mathrm{H}$ availability $[5,6,10]$.

AdhE1 (CA_P0162 gene product, also referred to as Aad) has long been considered as an NADH-dependent bifunctional alcohol/aldehyde dehydrogenase responsible for alcohol formation in solventogenic C. acetobutylicum cultures $[1,2,11]$. Recently, however, AdhE1 was purified and shown to have lost most of its alcohol dehydrogenase activity despite its NADH-dependent aldehyde dehydrogenase activity [12].

Prior to the identification of adhE2 (CA_P0035), the existence of alcohologenesis-specific gene(s) responsible for alcohol formation was predicted because (i) there was high NADH-dependent butanol dehydrogenase activity in alcohologenesis versus high NADPH-dependent butanol dehydrogenase activity in solventogenesis $[5,7]$ and (ii) previously identified genes related to butanol production (bdhA, bdhB, adhE1) were not induced in alcohologenic cultures [13]. The adhE2 gene is the second aldehyde/ alcohol dehydrogenase-encoding gene and is carried by the pSol1 megaplasmid, as is adhE1 [14]. The two genes are not clustered, in contrast to the observations for $C$. ljungdahlii [15] and their expression patterns differ [9, 12]. adhE1, ctfA, and ctfB (CA_P0163 and CA_P0164) form the sol operon $[1,11]$; $c t f A$ and $c t f B$ encode the CoAtransferase responsible for the first step of acetone formation, while the second step, catalyzed by acetoacetate decarboxylase, is encoded by adc (CA_P0165), located downstream of the sol operon. However, $a d c$ is transcribed under the control of its own promoter, which is oriented in the opposite direction of the sol operon [11].

In the three metabolic states, the contributions of the different enzymes responsible for the butyraldehyde dehydrogenase and butanol dehydrogenase activities to butanol flux have recently been characterized [12]. Under acidogenesis, the low butanol flux is catalyzed by AdhE2 (100 \%) for butyraldehyde dehydrogenase activity, while $\mathrm{BdhB}$ and BdhA are responsible for butanol dehydrogenase activity. Under solventogenesis, AdhE1 (95\%; the other $5 \%$ is contributed by AdhE2) is the key player responsible for butyraldehyde dehydrogenase activity, while BdhB, BdhA, and $\mathrm{BdhC}$ are responsible for butanol dehydrogenase activity. Under alcohologenesis, AdhE2 plays a major role in both butyraldehyde dehydrogenase $(100 \%)$ and butanol dehydrogenase activities. In the study of Cooksley et al. [16], adhE1 and adhE2 knockout mutants were (i) constructed using the ClosTron method [17] and (ii) phenotypically characterized in batch culture using Clostridium basal medium (CBMS) without $\mathrm{pH}$ adjustment. The adhE1 knockout mutant obtained in their study exhibited low ethanol and no butanol formation along with scant acetone production; these findings were consistent with the polar effect of the intron on $\operatorname{ctf} A B$ transcription [16]. Using the adhE2 knockout mutant, no alteration of solvent production was observed; however, the adhE2 knockout mutant has not been evaluated under alcohologenic conditions, under which it is normally thought to play a major role [14].

The aim of this study was to perform clean individual in-frame deletions of $a d h E 1$ and $a d h E 2$ to characterize their roles in butanol formation in the three different metabolic states in more detail. Furthermore, to study the metabolic flexibility of C. acetobutylicum in response to each of these gene deletions, a complete fluxomic and quantitative transcriptomic analysis was also performed in the three conditions known for the wild-type strains: acidogenic, solventogenic, and alcohologenic states. The results presented here not only support our previous studies $[12,14]$ on the roles of AdhE1 and AdhE2 in butanol formation in different metabolic states but also highlight the metabolic flexibility of $C$. acetobutylicum to genetically alter its primary metabolism.

\section{Results and discussion \\ Construction of $\triangle a d h E 1$ and $\triangle a d h E 2$ mutant strains}

Construction of the $\triangle a d h E 2$ mutant was relatively straightforward, as adhE2 is expressed in a monocistronic operon [14] (Fig. 1a). However, the position of $a d h E 1$ as the first gene of the sol operon made the construction of $\triangle a d h E 1$ more complicated because the transcription of downstream ctfAB genes could be affected. Figure $1 \mathrm{~b}-\mathrm{d}$ shows different configurations of the sol operon promoter, ctfAB genes, and either catP cassette with two FRT (Flippase Recognition Target) sites or a single FRT site remaining after Flippase (Flp)-FRT recombination of the three different types of $\triangle a d h E 1$ mutants generated in this study. The first constructed $\triangle a d h E 1$ mutant, $\Delta C A \_C 1502 \Delta$ upp $\triangle a d h E 1:: c a t P$ (Fig. 1b), was unable to form acetone as predicted because a transcriptional terminator was included in the catP cassette, which is located upstream of $c t f A B$ encoding the acetoacetyl coenzyme A:acetate/butyrate:coenzyme A transferase that is responsible for the first specific step of acetone formation [11]. However, after removing the catP cassette from $\triangle C A \_C 1502 \Delta u p p \Delta a d h E 1:: c a t P$, acetone production was unexpectedly not recovered in $\triangle C A \_C 1502 \Delta u p p \Delta a d h E 1$ (Fig. 1c). The presence of the megaplasmid pSOL1 was confirmed by the production of ethanol and butanol under alcohologenic conditions and was attributed to adhE2 expression. By sequencing the pSOL1 region around the adhE1 deletion, we confirmed that there was no mutation in the sol promoter, $c t f A B$ and $a d c$ (encoding acetoacetate decarboxylase, which is responsible for the last step of acetone production). Based on these results, the possibility of unsuspected 


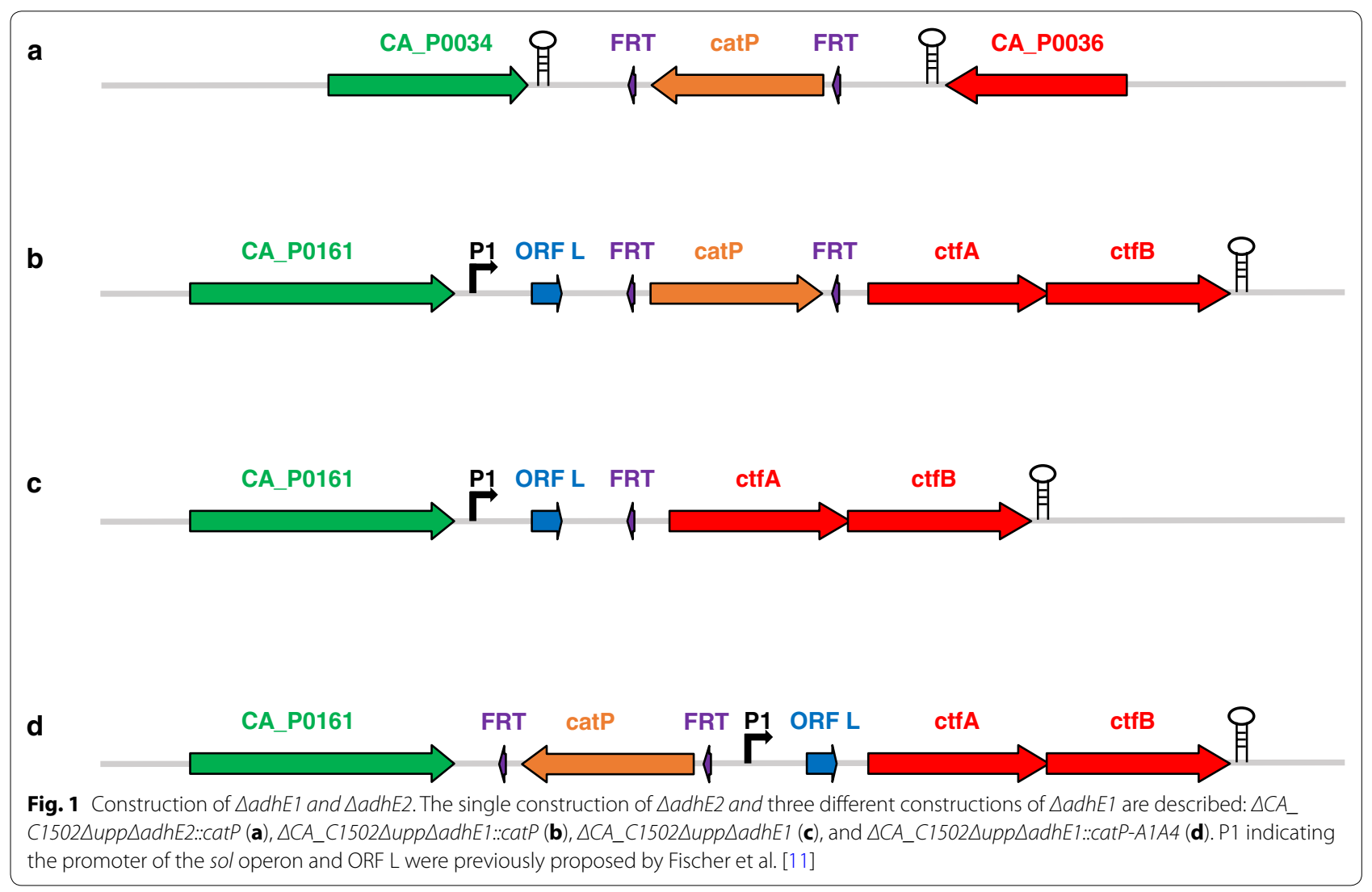

early transcriptional termination by the FRT site remaining after catP removal was deduced. To confirm the early termination of transcription by an FRT site and to eliminate this polar effect on acetone production, a new plasmid was constructed to position both of the FRT sites carried by the catP cassette upstream of the sol operon promoter and was used to construct the $\triangle a d h E 1$ mutant $\triangle C A \_C 1502 \Delta u p p \triangle a d h E 1:: c a t P-A 1 A 4$ mutant (Fig. 1d). Consistent with our hypothesis, this last $\triangle a d h E 1$ mutant recovered acetone production (Fig. 2, Additional file 1: Fig. S3). To the best of our knowledge, the potential role of an FRT site as a transcriptional terminator was reported once in Salmonella [18] and twice in yeast [19, 20], although the FRT site is not generally recognized as possessing this additional activity. However, the high score of the FRT site hit from the "Dimers and Hairpin Loops analysis" in Vector NTI software (Invitrogen) and the detection of this activity upon deleting adhE1 in $C$. acetobutylicum unambiguously demonstrate that the FRT site can function as a transcriptional terminator.

Hereafter, C.acetobutylicum $\triangle C A$ C1502 $\Delta$ uppDadhE1:: catP-A1A4 (Fig. 1d) is referred to as $\triangle a d h E 1$ in all the chemostat culture experiments.
Carbon and electron fluxes of $\triangle a d h E 1$ and $\triangle a d h E 2$ mutants under different physiological conditions

The $\triangle a d h E 1$ and $\triangle a d h E 2$ mutants were first evaluated under acidogenic conditions and compared to previously published data for the control strain [12]. All the strains behaved the same, and no significant changes in the metabolic fluxes were recorded (Additional file 1: Fig. S3), except that butanol production was completely abolished in the $\triangle a d h E 2$ mutant strain (Fig. 2, Additional file 1: Fig. S3).

The two mutant strains were then evaluated under solventogenic conditions and compared to previously published data for the control strain [12]. The control and $\triangle a d h E 2$ strains behaved the same, with no significant change in metabolic fluxes (Additional file 1: Fig. S3). However, the $\triangle a d h E 1$ mutant exhibited a completely different behavior. In the first phase, before the "pseudo steady state" was reached, this mutant exhibited considerable fluctuations in growth, glucose consumption, and metabolite profiles. Under "pseudo steady state conditions," the butanol and acetone fluxes were stable, while the butyrate flux showed fluctuations between 2.2 and $2.9 \mathrm{mmol} \mathrm{g}^{-1} \mathrm{~h}^{-1}$. In $\triangle a d h E 1$, the butanol, ethanol, and 

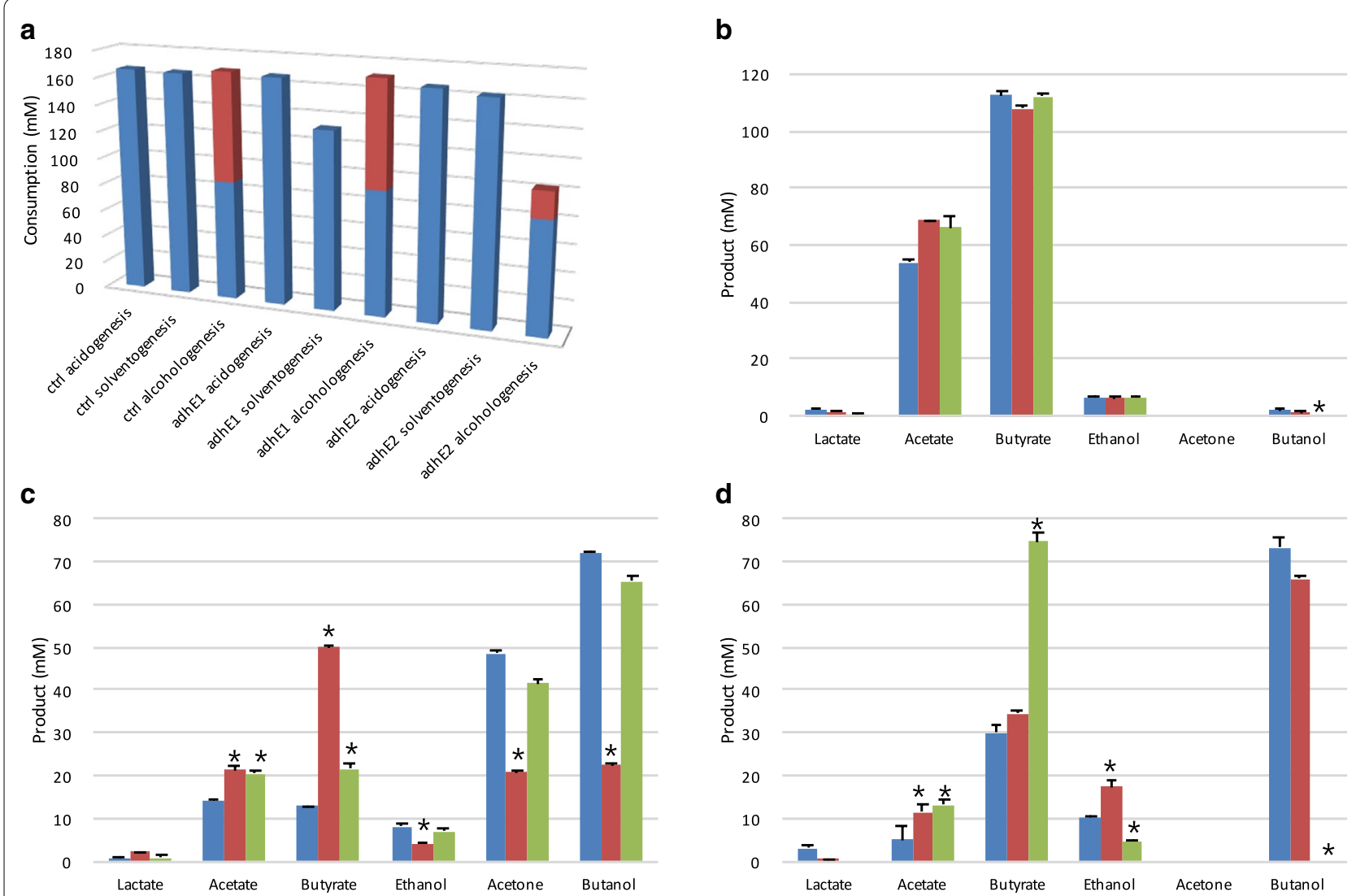

Fig. 2 Substrates and products profile under three different conditions for the control, $\triangle a d h E 1$ and $\triangle a d h E 2$ strains. a Carbon source consumption: glucose (blue) and glycerol (red). Product profiles in acidogenesis (b), solventogenesis (c), and alcohologenesis (d). For (b), (c), and (d), each histogram indicates different strains: control (blue), $\triangle a d h E 1$ (red), and $\triangle a d h E 2$ (green). Each error bar indicates the SEM from the mean of duplicate samples. *The value is significantly different from the value of the control at the $1 \%$ level based on the $P$ value obtained from Student's T-test

acetone fluxes decreased by 60,49 , and $46 \%$, respectively (Additional file 1: Fig. S3), compared to the control strain; thus, the acetone and ethanol fluxes were not reduced as greatly as the butanol fluxes. These results support the previously proposed $[1,11,12,14]$ key role of AdhE1 in butanol production under solventogenic conditions and demonstrate that an $a d h E 1$ knockout strain with no polar effect on $\operatorname{ctf} A B$ transcription can still produce acetone. The level of $\operatorname{ctf} A B$ expression was 3-fold higher in the adhE1 knockout compared to the control strain. This indicates that the lower flux of acetone production is the result of a control at the enzyme level due to a lower acetoacetyl-CoA concentration and/or higher acetyl-CoA/ butyryl-CoA concentrations. The remaining ability of the $\triangle a d h E 1$ strain to produce butanol under solventogenesis is explained by the higher adhE2 expression ( 127 -fold higher than the control strain, but only 25 mRNA molecules/cell) (Table 1, Additional file 2: Dataset S1). For the $\triangle a d h E 1$ mutant, the butyrate flux increased by 5 -fold compared to the control strain (Additional file 1: Fig. S3), although neither ptb-buk (CA_C3076-CA_C3075) nor buk2 (CA_C1660) experienced a significant transcriptional increase (Additional file 2: Dataset S1). Thus, flux is controlled at the enzyme level via an increase in the butyryl-CoA pool due to the lower flux in the butanol pathway. However, as the AdhE2 level in the mutant is the same as the AdhE1 level in the control $\left(6.31 \times 10^{4}\right.$ versus $5.99 \times 10^{4}$ protein molecules/cell), the lower flux of butanol production can be explained by (i) a lower catalytic efficiency of AdhE2 for butyryl-CoA and/or NADH or (ii) a lower intracellular $\mathrm{pH}$ under solventogenic conditions that would be less optimal for AdhE2 that is normally expressed under alcohologenic conditions at neutral $\mathrm{pH}$. The second hypothesis can be eliminated as the previously measured intracellular $\mathrm{pH}[4,21]$ in solventogenic and alcohologenic cells are relatively close (5.5 and 5.95, respectively) as the $\Delta \mathrm{pH}$ is inverted (more acidic inside) under alcohologenic conditions [6]. Finally, as we will see below, the fact that ethanol flux is less affected than the butanol flux might be explained by the existence of an ethanol flux through the Pdc (pyruvate decarboxylase, encoded by CA_P0025) and bdhA/BdhB. 
Table 1 Transcriptional changes of genes coding for the six key enzymes for alcohol production

\begin{tabular}{|c|c|c|c|}
\hline Metabolic state/gene & Control & $\triangle a d h E 1$ & $\triangle a d h E 2$ \\
\hline \multicolumn{4}{|l|}{ Acidogenesis } \\
\hline adhE1 (CA_P0162) & $0.09 \pm 0.01$ & $0 \pm 0$ & $0.2 \pm 0.01$ \\
\hline adhE2 (CA_P0035) & $0.42 \pm 0.02$ & $2.31 \pm 0.6$ & $0 \pm 0$ \\
\hline bdhA (CA_C3299) & $8.15 \pm 0.32$ & $4.33 \pm 1.03$ & $5.76 \pm 0.2$ \\
\hline bdhB (CA_C3298) & $16.31 \pm 0.45$ & $5.13 \pm 4.28$ & $1.52 \pm 0.11$ \\
\hline bdhC (CA_C3392) & $8.63 \pm 0.94$ & $7.55 \pm 0.28$ & $17.65 \pm 0.44$ \\
\hline pdc (CA_P0025) & $5.6 \pm 0.81$ & $1.74 \pm 0.1$ & $3.23 \pm 0.24$ \\
\hline \multicolumn{4}{|l|}{ Solventogenesis } \\
\hline adhE1 (CA_P0162) & $7.09 \pm 0.73$ & $0 \pm 0$ & $11.4 \pm 4.71$ \\
\hline adhE2 (CA_P0035) & $0.21 \pm 0.02$ & $26.6 \pm 0.26$ & $0 \pm 0$ \\
\hline bdhA (CA_C3299) & $8.22 \pm 1.33$ & $4.62 \pm 0.06$ & $7.55 \pm 0.75$ \\
\hline bdhB (CA_C3298) & $28.1 \pm 5.07$ & $34.78 \pm 1.55$ & $17.76 \pm 2.83$ \\
\hline bdhC (CA_C3392) & $11.28 \pm 1.68$ & $12.52 \pm 0.36$ & $9.16 \pm 0.67$ \\
\hline pdc (CA_P0025) & $5.17 \pm 2.78$ & $6.59 \pm 0.3$ & $6.23 \pm 1.03$ \\
\hline \multicolumn{4}{|l|}{ Alcohologenesis } \\
\hline adhE1 (CA_P0162) & $0.13 \pm 0.01$ & $0 \pm 0$ & $0.18 \pm 0.01$ \\
\hline adhE2 (CA_P0035) & $68.6 \pm 12.95$ & $62.56 \pm 7.58$ & $0 \pm 0$ \\
\hline bdhA (CA_C3299) & $6.08 \pm 0.37$ & $4.82 \pm 0.13$ & $7.39 \pm 0.21$ \\
\hline bdhB (CA_C3298) & $14.33 \pm 2.65$ & $16.96 \pm 0.25$ & $15.16 \pm 0.46$ \\
\hline bdhC (CA_C3392) & $10.73 \pm 0.94$ & $11.05 \pm 0.25$ & $8.95 \pm 0.32$ \\
\hline pdc (CA_P0025) & $1.23 \pm 0.51$ & $0.83 \pm 0.03$ & $1.86 \pm 0.07$ \\
\hline
\end{tabular}

The numbers of mRNA molecules per cell are shown as mean values \pm SD from three biological replicates

The two mutant strains were also evaluated under alcohologenic conditions and compared to previously published data for the control strain [12]. The control and $\triangle a d h E 1$ strains behaved the same, with no significant changes in metabolic fluxes (Additional file 1: Fig. S3). However, the $\triangle a d h E 2$ mutant exhibited a completely different behavior; no flux toward butanol was detected, whereas fluxes toward butyrate became the primary fluxes, as opposed to butanol in the control strain (Additional file 1: Fig. S3). In addition, acetate levels increased by $\sim 3$-fold, and such changes were accompanied by changes in electron fluxes (Fig. 3), which are described in detail below. These phenomena were not observed by Cooksley et al. [16] with their adhE2 knockout mutant, as they performed batch fermentation without promoting alcohologenic conditions. As adhE1 was not expressed under the "alcohologenic conditions" of the $\triangle a d h E 2$ mutant, the physiological function of adhE2 does not appear to be compensated by $a d h E 1$ (Table 1 ). To verify that loss of the butanol-producing ability under alcohologenesis did not result from loss of the pSOL1 megaplasmid [22, 23] but rather from the deletion of $a d h E 2$, the culture was switched to solventogenic conditions before the experiment was ended; under solventogenic conditions, high butanol and acetone production fluxes were recovered (data not shown).

The butanol pathway was analyzed for three different conditions in the respective mutants (Additional file 1: Fig. S2) by calculating the contribution of each of the five enzymes potentially involved in each of the two steps to the fluxes (see methods for the calculation).

Under acidogenesis, adhE1 was not expressed, and thus AdhE1 could not replace AdhE2 for the conversion of butyryl-CoA to butyraldehyde in the $\triangle a d h E 2$ mutant (Additional file 1: Fig. S2). This failure of AdhE1 to replace AdhE2 led to the absence of butanol production in the $\triangle a d h E 1$ mutant, which behaved the same as the control strain, leaving AdhE2 responsible for all the conversion. The $\triangle a d h E 1$ mutant behaved the same as the control strain with respect to the conversion of butyraldehyde to butanol under these conditions, and AdhE2 ( $45 \%$ of the flux), BdhB (34\% of the flux), and BdhA (14\% of the flux) were the main contributors (Additional file 1: Fig. S2). The $\triangle a d h E 2$ mutant was not analyzed because it does not produce butanol.

Under solventogenesis, AdhE2 replaced AdhE1 for the conversion of butyryl-CoA to butyraldehyde in the $\triangle a d h E 1$ mutant, while in the $\triangle a d h E 2$ mutant, which behaved the same as the control strain, AdhE1 was responsible for all the conversion. The two main contributors to the conversion of butyraldehyde to butanol under these conditions were AdhE2 (67\% of the flux) and BdhB (30\% of the flux) in the $\triangle a d h E 1$ mutant, while in the $\triangle a d h E 2$ mutant, which behaved the same as the control strain, BdhB ( $75 \%$ of the flux) and BdhA ( $16 \%$ of the flux) were the main contributors (Additional file 1: Fig. S2).

Under alcohologenesis, adhE1 was not expressed (Table 1, Additional file 2: Dataset S1), and thus, AdhE1 could not replace AdhE2 for the conversion of butyrylCoA to butyraldehyde in the $\triangle a d h E 2$ mutant. This failure of AdhE1 to replace AdhE2 led to the absence of butanol production, while in the $\triangle a d h E 1$ mutant, which behaved the same as the control strain, AdhE2 was responsible for all the conversion. The $\triangle a d h E 1$ mutant behaved the same as the control strain with respect to the conversion of butyraldehyde to butanol under these conditions, and AdhE2 was the main contributor (Additional file 1: Fig. S2). The $\triangle a d h E 2$ mutant was not analyzed because it does not produce butanol.

Two possible routes are known for the conversion of pyruvate to acetaldehyde in C. acetobutylicum: (i) a twostep reaction by pyruvate:ferredoxin oxidoreductase (PFOR) and acetaldehyde dehydrogenase via acetyl-CoA production or (ii) a one-step reaction by pyruvate decarboxylase (Pdc, encoded by CA_P0025) [24]. In the wildtype strain, the former route is considered as the primary pathway [2, 25]. Under acidogenic and alcohologenic 


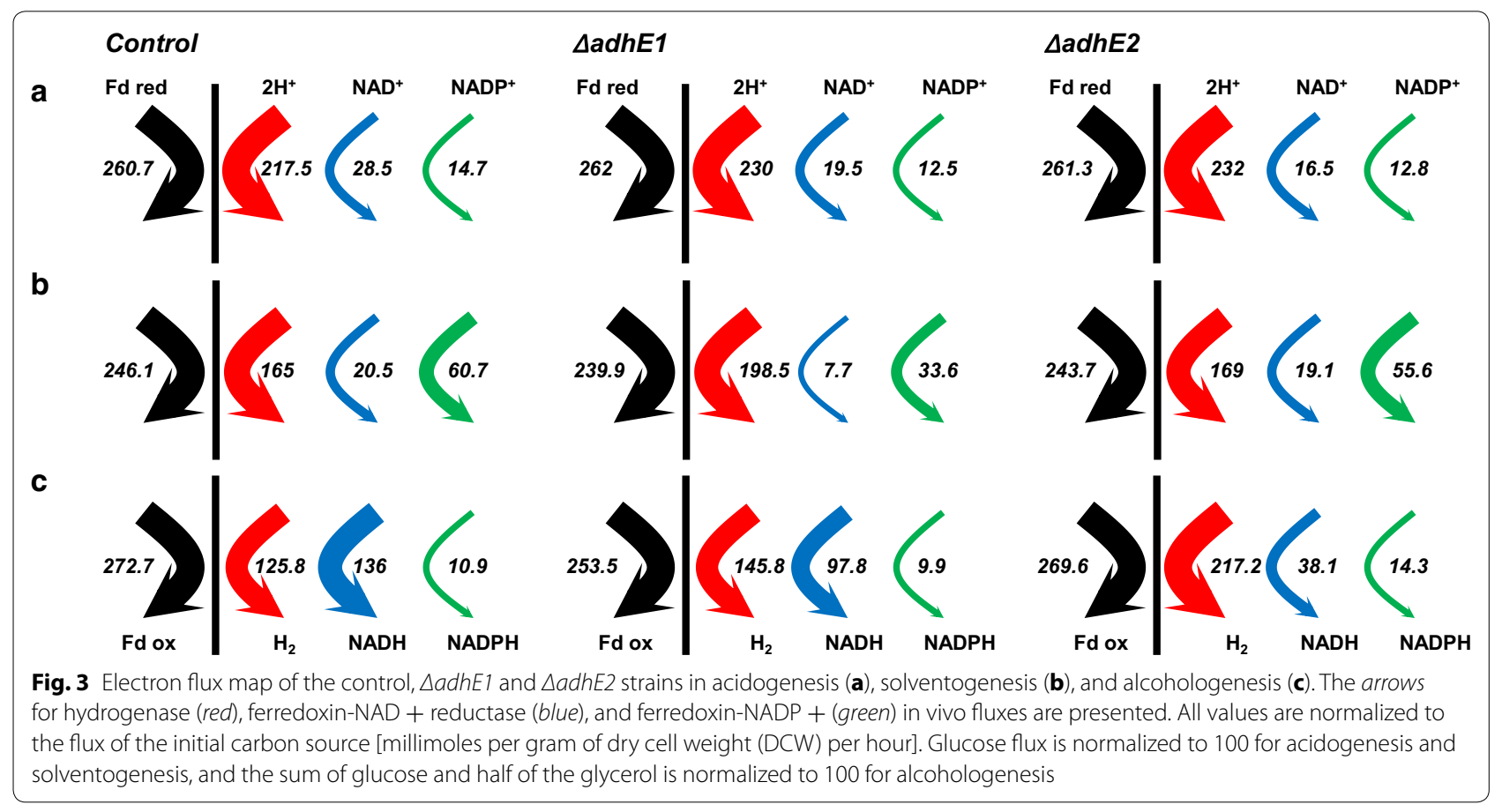

conditions of the $\triangle a d h E 2$ mutant, ethanol production was observed, but no butanol production was detected (Fig. 2, Additional file 1: Fig. S3). As previously reported [12], AdhE1 retains only aldehyde dehydrogenase activity, whereas AdhE2 possesses both aldehyde and alcohol dehydrogenases activities. Thus, the ethanol production of the $\triangle a d h E 2$ mutant suggests that the latter route is active. In other words, Pdc could be functional, and the ethanol dehydrogenase activity in acidogenesis could be due to BdhA, BdhB, or BdhC (Table 1). The same pathway might also be functional in solventogenesis and explains why in the $\triangle a d h E 1$ mutant the ethanol flux was less affected than the butanol flux.

Because the predominant use of reduced ferredoxin is for hydrogen production [12], no significant effects were observed under acidogenesis in both the $\triangle a d h E 1$ and $\triangle a d h E 2$ mutants with respect to electron flux (Fig. 3). In addition, solventogenesis of the $\triangle a d h E 2$ mutant exhibited similar flux levels to the control strain due to the small contribution of AdhE2 (5\% for butyraldehyde dehydrogenase function and $9 \%$ for butanol dehydrogenase function) under these conditions in the control strain. However, under the same conditions as for $\triangle a d h E 1$, both the fluxes for $\mathrm{NADH}$, known as the partner of AdhE1 and AdhE2, and for NADPH, known as the partner of BdhA, $\mathrm{BdhB}$, and BdhC, were reduced (by $\sim 2.7$-fold and 1.8fold, respectively) due to decreased carbon fluxes toward alcohols (Fig. 3, Additional file 1: Fig. S3). The most striking changes were observed in the $\triangle a d h E 2$ mutant under alcohologenesis, in which the primary use of reduced ferredoxin was switched from NADH to hydrogen production. The absence of butanol formation resulted in a $\sim 3.6$-fold decreased flux toward NADH production and a 1.7-fold increased flux toward hydrogen production (Fig. 3).

\section{Common criteria used for quantitative transcriptomic analysis}

To filter the data from only significant results, the same criteria used to compare the wild-type strain under different physiological conditions [12] were used to compare the mutants to the control strain. The first criterion was $>4.0$-fold higher expression or $>4.0$-fold lower expression in $\triangle a d h E 1$ or $\triangle a d h E 2$ than in the control strain under the same physiological condition, and the second criterion was $>0.2$ mRNA molecules per cell in at least one of the two strains being compared.

\section{Genes affected by adhE1 or adhE2 deletion under acidogenesis}

As alcohols are minor products under acidogenesis, the deletion of adhE1 or adhE2 did not significantly alter the metabolic flux map (Additional file 1: Fig. S3). However, a surprisingly large number of genes (100 genes increased in $\triangle a d h E 1,108$ genes decreased in $\triangle a d h E 1,119$ genes increased in $\triangle a d h E 2,170$ genes decreased in $\triangle a d h E 2)$ showed significant changes in mRNA molecules/cell in response to the deletion of each gene (Table 2). Furthermore, 50 genes (>4-fold increase) and 87 genes (>4-fold 
decrease) revealed the same patterns of change in both the $\triangle a d h E 1$ and $\triangle a d h E 2$ mutants (Table 2). The primary metabolism-related genes that influence metabolic fluxes did not exhibit significant changes, whereas mostly subordinate metabolism-related genes were affected (Additional file 1: Table S2, Additional file 1: S3, and Fig. 4).

Interestingly, a large portion (18 genes showed >a 4 -fold increase, and 2 genes showed a $>2.8$-fold increase out of 30 genes proposed by Wang et al. [26]) of the cysteine metabolism regulator (CymR) regulon showed significantly increased expression in both mutants under acidogenesis (CymR regulons are indicated in Table 3). In particular, an operon involved in cysteine and sulfur metabolism (CA_C0102-CA_C0110) showed a >10-fold increase in both mutants. This operon was reported to respond to butyrate/butanol stresses and to be up-regulated under alcohologenesis in wild-type strains [12, 26, 27] and under solventogenesis in the $\Delta p t b$ mutant [28]. In addition, the expression of two putative cysteine $A B C$ transporter operons belonging to the CymR regulon [26, 27], namely CA_C0878-CA_C0880 and CA_C3325CA_C3327), was also up-regulated.

A long gene cluster linked to iron/sulfur/molybdenum metabolism (CA_C1988-CA_C2019) exhibited significantly decreased expression (except for CA_C1988, CA_C1990, CA_C1992 and CA_C1995, for which some values were below the significance criterion of 4-fold but were higher than 3-fold) (Table 3, Additional file 2: Dataset S1). A part of this cluster, CA_C1988-CA_C1996, was previously reported to be down-regulated under oxygen-exposed conditions [29]. Moreover, this cluster was shown by Schwarz et al. [30] to be repressed by butanol stress in an acidogenic chemostat.

\section{Transcriptional changes due to adhE1 or adhE2 deletion under solventogenesis}

Under solventogenesis, a drastic change in fluxes was observed in the $\triangle a d h E 1$ mutant, while the fluxes remained unchanged in the $\triangle a d h E 2$ mutant; additionally, as expected, more genes showed significant changes in $\triangle a d h E 1$ than in $\triangle a d h E 2$ (Table 2, Additional file 1: Table S4, Additional file 1: S5). Specifically, in $\triangle a d h E 1,55$ genes were up-regulated, and 127 genes were down-regulated (Table 2). In $\triangle a d h E 2,22$ genes were up-regulated, and 17 genes were down-regulated (Table 2). In contrast to the observations previously made under acidogenesis, no gene was significantly increased in both the $\triangle a d h E 1$ and $\triangle a d h E 2$ mutants, and only 1 gene (CA_C3612, encoding a hypothetical protein) was significantly decreased in both mutants.

In $\triangle a d h E 1$, the CA_C0102-CA_C0110 operon which was shown to be up-regulated in acidogenesis and belongs to the CymR regulon, was also up-regulated by $>18$-fold under solventogenesis (Additional file 1: Table S4). However, the up-regulation of this operon (under alcohologenesis in the control strain, acidogenesis and solventogenesis in $\triangle a d h E 1$, or acidogenesis in $\triangle a d h E 2$ ) did not have striking shared features with the main product profile.

Interestingly, expression of the natAB operon $\left(\mathrm{CA}_{-}\right.$ C3551-CA_C3550) (>10-fold), encoding a potential $\mathrm{Na}^{+}-\mathrm{ABC}$ transporter, and the $k d p$ gene cluster $\left(\mathrm{CA}_{-}\right.$ C3678-CA_C3682), encoding a potential $\mathrm{K}^{+}$transporter ( $>20$-fold), was highly up-regulated under solventogenesis (Additional file 1: Table S4, Additional file 2: Dataset $\mathrm{S} 1$ ) in $\triangle a d h E 1$. The nat $A B$ operon and the $k d p$ gene cluster have previously been reported to be up-regulated by both acetate and butyrate stress [27]. As the ability of the $\triangle a d h E 1$ mutant to produce butanol was highly affected and as butyrate and acetate were the primary fermentation products (Fig. 2), this strain struggled to survive under acidic conditions (i.e., under the $\mathrm{pH}$ of 4.4 for solventogenesis); consequently, genes involved in ion transport were up-regulated.

The operon CA_P0029-CA_P0030, which potentially encodes a transporter and an isochorismatase, was upregulated under acidogenesis in both mutants as well as

Table 2 Numbers of significantly changed genes by each gene deletion and genes exhibiting the same pattern of change for both deletions under three different metabolic states (the genes exhibiting the same pattern for both deletions under acidogenesis are listed in Table 3)

\begin{tabular}{|c|c|c|c|c|}
\hline & $\triangle a d h E 1$ & $\triangle a d h E 2$ & $\begin{array}{l}\text { Same pattern in } \\
\triangle a d h E 1 \text { and } \triangle a d h E 2\end{array}$ & Note $^{a}$ \\
\hline Up-regulation under acidogenesis & 100 & 119 & 50 & Most CymR regulons are included \\
\hline Down-regulation under acidogenesis & 108 & 170 & 89 & $\begin{array}{l}\text { Most butanol response genes } \\
\text { are included }\end{array}$ \\
\hline Up-regulation under solventogenesis & 55 & 22 & 0 & \\
\hline Down-regulation under solventogenesis & 127 & 17 & 1 & CA_C3612 \\
\hline Up-regulation under alcohologenesis & 1 & 35 & 0 & \\
\hline Down-regulation under alcohologenesis & 14 & 38 & 1 & CA_C3274 \\
\hline
\end{tabular}

a Representative features or locus number of the sole gene showing same pattern under certain condition are shown 


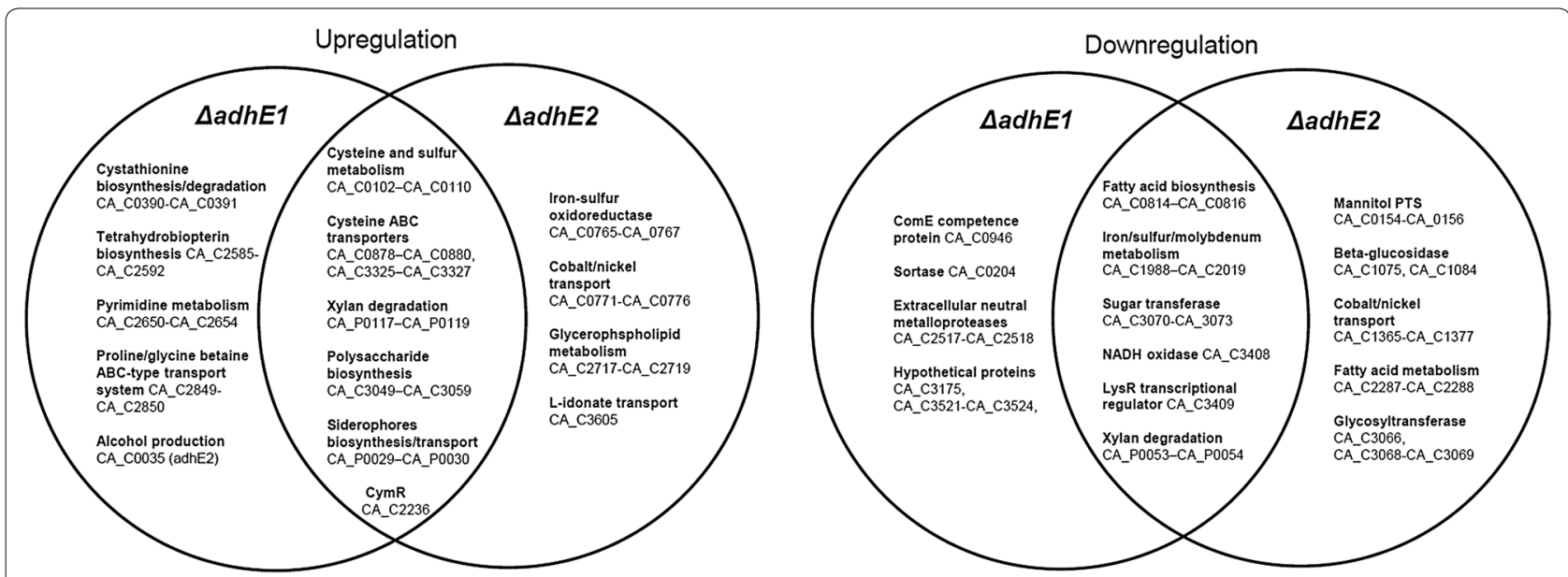

Fig. 4 Venn diagrams of representative genes with involved pathways, which matched the significance criteria (>4-fold increase or decrease) in the $\triangle a d h E 1$ and $\triangle a d h E 2$ mutants. A complete list of each metabolic condition is provided in the Additional file 2

under solventogenesis in $\triangle a d h E 2$ ( $>20$-fold) (Table 2, Additional file 1: Table S5). Two neighboring genes, CA C3604 (ilvD), encoding dihydroxyacid dehydratase linked to valine/leucine/isoleucine biosynthesis, and CA_C3605 $(g n t P)$, encoding high affinity gluconate/L-idonate permease, exhibited striking increases ( $>120$-fold) (Additional file 1: Table S5) in $\triangle a d h E 2$.

As described above, the solventogenic culture of $\triangle a d h E 1$ has a lower glucose consumption rate than the control strain (Fig. 2) and consequently more glucose remained unconsumed in the medium. Accordingly, numerous genes related to sugar metabolism were downregulated under this metabolic state. For instance, all the structural genes on the mannitol phosphotransferase system (PTS)-related operon mtlARFD (CA_C0154CA_C0157) and the mannose PTS-related operon (CA_P0066-CA_P0068) were decreased by $>10$-fold (Additional file 1: Table S4).

Interestingly, one of two operons encoding a quorumsensing system and putatively involved in sporulation, CA_C0078-CA_C0079 (agrBD) [31], was strongly downregulated (infinity-fold for CA_C0078 and 667-fold for CA_C0078) in $\triangle a d h E 2$ relative to the control strain (Additional file 1: Table S5). However, the other operon, CA_C0080-CA_C0081 (agrCA), did not significantly change ( $<3$-fold decreases) (Additional file 2: Dataset S1). Quantitatively, less than 1 agrCA mRNA molecule was found per cell, whereas more than 1 agrBD mRNA molecule was found per cell under all conditions in the control strain [12]. These different expression levels are not surprising because $a g r B D$ and $a g r C A$ are independently transcribed [31-33]. In addition, agrBD was repressed under all conditions in $\triangle a d h E 2$, although the sporulation of this mutant was not affected (Additional file 2: Dataset S1).

\section{Transcriptional changes due to adhE1 or adhE2 deletion} under alcohologenesis

Under alcohologenesis, a drastic change in fluxes was observed in the $\triangle a d h E 2$ mutant, while in the $\triangle a d h E 1$ mutant, the fluxes remained unchanged. As expected, more genes showed significant changes in the $\triangle a d h E 2$ mutant than in the $\triangle a d h E 1$ mutant (Table 2). Specifically, in $\triangle a d h E 1$, only 1 gene was up-regulated $(\operatorname{agrB})$, and 14 genes were down-regulated, while in $\triangle a d h E 2,35$ genes were up-regulated, and 38 genes were down-regulated.

The most dynamic changes in the $\triangle a d h E 2$ mutant were observed in CA_C3604 (ilvD, 297-fold) and CA_C3605 (gntP, 301-fold) (Additional file 1: Table S7). As mentioned previously, these genes were highly up-regulated (>84-fold) under all the conditions in the $\triangle a d h E 2$ mutant (Additional file 2: Dataset S1). Interestingly, two genes located immediately downstream of adhE2, CA_P0036, which encodes a cytosolic protein of unknown function, and CA_P0037, which encodes a potential transcriptional regulator, exhibited a $\sim 9$-fold increase under alcohologenesis (Additional file 1: Table S7) in $\triangle a d h E 2$.

A sucrose metabolism operon comprising scrAKB ( $\mathrm{CA}_{-}$ C0423-CA_C0425), encoding a PTS IIBCA domain on a single gene, fructokinase and sucrose-6-P hydrolase [35, 36], was strikingly down-regulated ( $>47$-fold) (Additional file 1 : Table S6). Moreover, the gene immediately upstream, scrT (CA_C0422) (encoding a putative transcriptional antiterminator), and the gene downstream, CA_C0426, encoding a putative AraC-type of regulator, were also decreased, by 9.3fold and 8-fold, respectively (Additional file 1: Table S6). The similar expression patterns of CA_C0422, CA_C0426, and $s c r A K B$ support the hypotheses of previous studies regarding their roles in regulating $\operatorname{scr} A K B[35,36]$. 
Table 3 Genes exhibiting the same pattern of change for both deletions under acidogenesis

\begin{tabular}{|c|c|c|c|c|}
\hline Locus number & Function & $\triangle a d h E 1 / C o n t r o l$ strain & $\triangle a d h E 2 / C o n t r o l$ strain & Note $^{a}$ \\
\hline \multicolumn{5}{|l|}{ Up-regulation } \\
\hline CA_C0102 & O-acetylhomoserine sulfhydrylase & 28.70 & 20.49 & CymR \\
\hline CA_C0103 & Adenylylsulfate kinase & 32.55 & 22.06 & CymR \\
\hline CA_C0104 & Adenylylsulfate reductase, subunit A & 48.44 & 28.89 & CymR \\
\hline CA_C0105 & Ferredoxin & 30.78 & 21.84 & CymR \\
\hline CA_C0106 & $\begin{array}{l}\text { ABC-type probable sulfate transporter, peri- } \\
\text { plasmic binding protein }\end{array}$ & 26.09 & 14.54 & CymR \\
\hline CA_C0107 & $\begin{array}{l}\text { ABC-type sulfate transporter, ATPase com- } \\
\text { ponent }\end{array}$ & 22.86 & 13.03 & CymR \\
\hline CA_C0108 & $\begin{array}{l}\text { ABC-type probable sulfate transporter, per- } \\
\text { mease protein }\end{array}$ & 35.38 & 19.05 & CymR \\
\hline CA_C0109 & Sulfate adenylate transferase, CysD subfamily & 42.53 & 26.82 & CymR \\
\hline CA_C0110 & $\begin{array}{l}\text { GTPase, sulfate adenylate transferase subunit } \\
1\end{array}$ & 54.78 & 42.48 & CymR \\
\hline CA_C0117 & Chemotaxis protein cheY homolog & 8.34 & 6.69 & \\
\hline CA_C0118 & Chemotaxis protein cheA & 11.00 & 8.24 & \\
\hline CA_C0119 & Chemotaxis protein cheW & 13.83 & 9.52 & \\
\hline CA_C0120 & $\begin{array}{l}\text { Membrane-associated methyl-accepting } \\
\text { chemotaxis protein with HAMP domain }\end{array}$ & 6.93 & 5.29 & \\
\hline CA_C0878 & $\begin{array}{l}\text { Amino acid } A B C \text { transporter permease } \\
\text { component }\end{array}$ & 5.61 & 4.04 & CymR \\
\hline CA_C0879 & $\begin{array}{l}\text { ABC-type polar amino acid transport system, } \\
\text { ATPase component }\end{array}$ & 8.29 & 5.60 & CymR \\
\hline CA_C0880 & Periplasmic amino acid binding protein & 9.50 & 6.50 & CymR \\
\hline CA_C0930 & Cystathionine gamma-synthase & 4.58 & 4.72 & CymR \\
\hline CA_C1392 & $\begin{array}{l}\text { Glutamine phosphoribosylpyrophosphate } \\
\text { amidotransferase }\end{array}$ & 4.20 & 4.47 & \\
\hline CA_C1394 & $\begin{array}{l}\text { Folate-dependent phosphoribosylglycina- } \\
\text { mide formyltransferase }\end{array}$ & 4.11 & 4.57 & \\
\hline CA_C2072 & Stage IV sporulation protein B, SpolVB & $\infty$ & $\infty$ & \\
\hline CA_C2235 & $\begin{array}{l}\text { Cysteine synthase/cystathionine beta-syn- } \\
\text { thase, CysK }\end{array}$ & 8.27 & 7.17 & CymR \\
\hline CA_C2236 & $\begin{array}{l}\text { Uncharacterized conserved protein of YjeB/ } \\
\text { RRF2 family }\end{array}$ & 4.29 & 4.06 & CymR encoding gene \\
\hline CA_C2241 & Cation transport P-type ATPase & 7.92 & 7.62 & \\
\hline CA_C2242 & Predicted transcriptional regulator, arsE family & 5.01 & 5.22 & \\
\hline CA_C2521 & Hypothetical protein, CF-41 family & 4.33 & 5.70 & \\
\hline CA_C2533 & Protein containing ChW-repeats & $\infty$ & $\infty$ & \\
\hline CA_C2816 & Hypothetical protein, CF-17 family & 6.00 & 11.20 & \\
\hline CA_C3049 & Glycosyltransferase & 4.79 & 7.42 & \\
\hline CA_C3050 & $\begin{array}{l}\text { AMSJ/WSAK-related protein, possibly involved } \\
\text { in exopolysaccharide biosynthesis }\end{array}$ & 4.70 & 8.25 & \\
\hline CA_C3051 & Glycosyltransferase & 5.16 & 9.60 & \\
\hline CA_C3052 & Glycosyltransferase & 5.59 & 9.91 & \\
\hline CA_C3053 & Histidinol phosphatase-related enzyme & 7.03 & 10.94 & \\
\hline CA_C3054 & Phosphoheptose isomerase & 6.69 & 11.37 & \\
\hline CA_C3055 & Sugar kinase & 5.90 & 10.87 & \\
\hline CA_C3056 & $\begin{array}{l}\text { Nucleoside-diphosphate-sugar pyrophos- } \\
\text { phorylase }\end{array}$ & 6.37 & 11.28 & \\
\hline CA_C3057 & Glycosyltransferase & 12.36 & 11.92 & \\
\hline CA_C3058 & Mannose-1-phosphate guanylyltransferase & 9.94 & 11.59 & \\
\hline
\end{tabular}


Table 3 continued

\begin{tabular}{|c|c|c|c|c|}
\hline Locus number & Function & $\triangle a d h E 1 /$ Control strain & $\triangle a d h E 2 /$ Control strain & Note $^{a}$ \\
\hline CA_C3059 & Sugar transferases & 13.47 & 12.63 & \\
\hline CA_C3325 & Periplasmic amino acid binding protein & 18.24 & 10.68 & CymR \\
\hline CA_C3326 & $\begin{array}{l}\text { Amino acid ABC-type transporter, permease } \\
\text { component }\end{array}$ & 19.82 & 11.79 & CymR \\
\hline CA_C3327 & $\begin{array}{l}\text { Amino acid ABC-type transporter, ATPase } \\
\text { component }\end{array}$ & 28.33 & 16.73 & CymR \\
\hline CA_C3461 & Hypothetical protein & 4.52 & 16.79 & \\
\hline CA_C3556 & Probable S-layer protein; & 4.18 & 10.41 & \\
\hline CA_C3636 & $\begin{array}{l}\text { Oligopeptide ABC transporter, ATPase com- } \\
\text { ponent }\end{array}$ & 4.23 & 4.68 & \\
\hline CA_P0029 & Permease MDR-related & $\infty$ & $\infty$ & \\
\hline CA_P0030 & Isochorismatase & 385.91 & 81.89 & \\
\hline CA_P0031 & $\begin{array}{l}\text { Transcriptional activator HLYU, HTH of ArsR } \\
\text { family }\end{array}$ & 46.17 & 10.93 & \\
\hline CA_P0117 & $\begin{array}{l}\text { Possible beta-xylosidase diverged, family 5/39 } \\
\text { of glycosyl hydrolases and alpha-amylase C } \\
\text { (Greek key) C-terminal domain }\end{array}$ & 56.53 & 4.94 & \\
\hline CA_P0118 & $\begin{array}{l}\text { Possible xylan degradation enzyme (glycosyl } \\
\text { hydrolase family 30-like domain and Ricin } \\
\text { B-like domain) }\end{array}$ & 54.97 & 5.22 & \\
\hline CA_P0119 & $\begin{array}{l}\text { Possible xylan degradation enzyme (glycosyl } \\
\text { hydrolase family 30-like domain and Ricin } \\
\text { B-like domain) }\end{array}$ & 46.44 & 4.23 & \\
\hline \multicolumn{5}{|l|}{ Down-regulation } \\
\hline CA_C0078 & Accessory gene regulator protein $B$ & 0.04 & 0.00 & \\
\hline CA_C0079 & Hypothetical protein & 0.00 & 0.00 & \\
\hline CA_C0082 & Predicted membrane protein & 0.02 & 0.00 & \\
\hline CA_C0310 & $\begin{array}{l}\text { Regulators of stationary/sporulation gene } \\
\text { expression, abrB B.subtilis ortholog }\end{array}$ & 0.15 & 0.23 & \\
\hline CA_C0381 & Methyl-accepting chemotaxis protein & 0.18 & 0.13 & \\
\hline CA_C0437 & Sensory transduction histidine kinase & 0.15 & 0.23 & \\
\hline CA_C0537 & $\begin{array}{l}\text { Acetylxylan esterase, acyl-CoA esterase or } \\
\text { GDSL lipase family, strong similarity to } \\
\text { C-terminal region of endoglucanase E } \\
\text { precursor }\end{array}$ & 0.15 & 0.10 & \\
\hline CA_C0542 & Methyl-accepting chemotaxis protein & 0.21 & 0.08 & \\
\hline CA_C0658 & Fe-S oxidoreductase & 0.24 & 0.00 & \\
\hline CA_C0660 & Hypothetical protein, CF-26 family & 0.17 & 0.08 & $\mathrm{BuOH}$ \\
\hline CA_C0814 & 3-oxoacyl-[acyl-carrier-protein] synthase III & 0.11 & 0.02 & $\mathrm{BuOH}$ \\
\hline CA_C0815 & Methyl-accepting chemotaxis protein & 0.13 & 0.04 & $\mathrm{BuOH}$ \\
\hline CA_C0816 & Lipase-esterase-related protein & 0.17 & 0.04 & $\mathrm{BuOH}$ \\
\hline CA_C1010 & Predicted phosphohydrolase, Icc family & 0.21 & 0.04 & $\mathrm{BuOH}$ \\
\hline CA_C1022 & $\begin{array}{l}\text { Thioesterase II of alpha/beta hydrolase } \\
\text { superfamily }\end{array}$ & 0.22 & 0.11 & \\
\hline CA_C1078 & Predicted phosphohydrolase, Icc family & 0.17 & 0.04 & $\mathrm{BuOH}$ \\
\hline CA_C1079 & $\begin{array}{l}\text { Uncharacterized protein, related to enterotox- } \\
\text { ins of other Clostridiales }\end{array}$ & 0.15 & 0.05 & \\
\hline CA_C1080 & $\begin{array}{l}\text { Uncharacterized protein, probably surface- } \\
\text { located }\end{array}$ & 0.11 & 0.01 & \\
\hline CA_C1081 & $\begin{array}{l}\text { Uncharacterized protein, probably surface- } \\
\text { located }\end{array}$ & 0.13 & 0.01 & \\
\hline CA_C1532 & Protein containing ChW-repeats & 0.22 & 0.08 & \\
\hline CA_C1766 & Predicted sigma factor & 0.19 & 0.00 & \\
\hline CA_C1775 & Predicted membrane protein & 0.16 & 0.05 & \\
\hline
\end{tabular}


Table 3 continued

\begin{tabular}{|c|c|c|c|c|}
\hline Locus number & Function & $\triangle a d h E 1 /$ Control strain & $\triangle a d h E 2 /$ Control strain & Note $^{a}$ \\
\hline CA_C1868 & $\begin{array}{l}\text { Uncharacterized secreted protein, homolog } \\
\text { YXKC Bacillus subtilis }\end{array}$ & 0.22 & 0.18 & \\
\hline CA_C1989 & $\begin{array}{l}\text { ABC-type iron (III) transport system, ATPase } \\
\text { component }\end{array}$ & 0.18 & 0.11 & $\mathrm{BuOH}$ \\
\hline CA_C1991 & Uncharacterized protein, YIIM family & 0.23 & 0.10 & $\mathrm{BuOH}$ \\
\hline CA_C1993 & $\begin{array}{l}\text { Molybdenum cofactor biosynthesis enzyme } \\
\text { MoaA, Fe-S oxidoreductase }\end{array}$ & 0.23 & 0.18 & $\mathrm{BuOH}$ \\
\hline CA_C1994 & Molybdopterin biosynthesis enzyme, MoaB & 0.22 & 0.11 & $\mathrm{BuOH}$ \\
\hline CA_C1996 & Hypothetical protein & 0.19 & 0.08 & $\mathrm{BuOH}$ \\
\hline CA_C1997 & Predicted glycosyltransferase & 0.19 & 0.07 & $\mathrm{BuOH}$ \\
\hline CA_C1998 & $\begin{array}{l}\text { ABC-type transport system, ATPase compo- } \\
\text { nent }\end{array}$ & 0.19 & 0.07 & $\mathrm{BuOH}$ \\
\hline CA_C1999 & $\begin{array}{l}\text { Uncharacterized protein related to hypotheti- } \\
\text { cal protein Cj1507c from Campylobacter } \\
\text { jejuni }\end{array}$ & 0.20 & 0.07 & $\mathrm{BuOH}$ \\
\hline CA_C2000 & $\begin{array}{l}\text { Indolepyruvate ferredoxin oxidoreductase, } \\
\text { subunit beta }\end{array}$ & 0.19 & 0.06 & $\mathrm{BuOH}$ \\
\hline CA_C2001 & $\begin{array}{l}\text { Indolepyruvate ferredoxin oxidoreductase, } \\
\text { subunit alpha }\end{array}$ & 0.13 & 0.04 & $\mathrm{BuOH}$ \\
\hline CA_C2002 & Predicted iron-sulfur flavoprotein & 0.16 & 0.05 & $\mathrm{BuOH}$ \\
\hline CA_C2003 & Predicted permease & 0.16 & 0.08 & $\mathrm{BuOH}$ \\
\hline CA_C2004 & $\begin{array}{l}\text { Siderophore/Surfactin synthetase-related } \\
\text { protein }\end{array}$ & 0.10 & 0.04 & $\mathrm{BuOH}$ \\
\hline CA_C2005 & $\begin{array}{l}\text { Siderophore/Surfactin synthetase-related } \\
\text { protein }\end{array}$ & 0.12 & 0.05 & $\mathrm{BuOH}$ \\
\hline CA_C2006 & Enzyme of siderophore/surfactin biosynthesis & 0.15 & 0.07 & $\mathrm{BuOH}$ \\
\hline CA_C2007 & Predicted glycosyltransferase & 0.09 & 0.03 & $\mathrm{BuOH}$ \\
\hline CA_C2008 & 3-oxoacyl-(acyl-carrier-protein) synthase & 0.11 & 0.04 & $\mathrm{BuOH}$ \\
\hline CA_C2009 & 3-Hydroxyacyl-CoA dehydrogenase & 0.10 & 0.03 & $\mathrm{BuOH}$ \\
\hline CA_C2010 & Predicted Fe-S oxidoreductase & 0.09 & 0.03 & $\mathrm{BuOH}$ \\
\hline CA_C2011 & $\begin{array}{l}\text { Possible 3-oxoacyl-[acyl-carrier-protein] } \\
\text { synthase III }\end{array}$ & 0.12 & 0.03 & $\mathrm{BuOH}$ \\
\hline CA_C2012 & Enoyl-CoA hydratase & 0.12 & 0.04 & $\mathrm{BuOH}$ \\
\hline CA_C2013 & Hypothetical protein & 0.12 & 0.03 & $\mathrm{BuOH}$ \\
\hline CA_C2014 & Predicted esterase & 0.12 & 0.02 & $\mathrm{BuOH}$ \\
\hline CA_C2015 & Hypothetical protein & 0.15 & 0.04 & $\mathrm{BuOH}$ \\
\hline CA_C2016 & Enoyl-CoA hydratase & 0.12 & 0.02 & $\mathrm{BuOH}$ \\
\hline CA_C2017 & Acyl carrier protein & 0.15 & 0.03 & $\mathrm{BuOH}$ \\
\hline CA_C2018 & Aldehyde:ferredoxin oxidoreductase & 0.12 & 0.03 & $\mathrm{BuOH}$ \\
\hline CA_C2019 & Malonyl CoA-acyl carrier protein transacylase & 0.12 & 0.02 & $\mathrm{BuOH}$ \\
\hline CA_C2020 & $\begin{array}{l}\text { Molybdopterin biosynthesis enzyme, MoeA, } \\
\text { fused to molybdopterin-binding domain }\end{array}$ & 0.20 & 0.07 & \\
\hline CA_C2021 & $\begin{array}{l}\text { Molybdopterin biosynthesis enzyme, MoeA } \\
\text { (short form) }\end{array}$ & 0.24 & 0.06 & \\
\hline CA_C2023 & $\begin{array}{l}\text { Membrane protein, related to copy number } \\
\text { protein COP from Clostridium perfringens } \\
\text { plasmid pIP404 (Gl:116,928) }\end{array}$ & 0.22 & 0.12 & \\
\hline CA_C2026 & Predicted flavodoxin & 0.20 & 0.09 & \\
\hline CA_C2107 & Contains cell adhesion domain & 0.20 & 0.08 & \\
\hline CA_C2293 & Hypothetical secreted protein & 0.13 & 0.10 & \\
\hline CA_C2581 & $\begin{array}{l}\text { 6-pyruvoyl-tetrahydropterin synthase-related } \\
\text { domain; conserved membrane protein }\end{array}$ & 0.24 & 0.11 & $\mathrm{BuOH}$ \\
\hline CA_C2663 & Protein containing cell wall hydrolase domain & 0.23 & 0.09 & \\
\hline
\end{tabular}


Table 3 continued

\begin{tabular}{|c|c|c|c|c|}
\hline Locus number & Function & $\triangle a d h E 1 /$ Control strain & $\triangle a d h E 2 /$ Control strain & Note $^{a}$ \\
\hline CA_C2695 & $\begin{array}{l}\text { Diverged Metallo-dependent hydrolase(Zn) } \\
\text { of DD-Peptidase family; peptodoglycan- } \\
\text { binding domain }\end{array}$ & 0.17 & 0.12 & $\mathrm{BuOH}$ \\
\hline CA_C2807 & Endo-1,3(4)-beta-glucanase family 16 & 0.21 & 0.02 & \\
\hline CA_C2808 & $\begin{array}{l}\text { Beta-lactamase class C domain (PBPX family) } \\
\text { containing protein }\end{array}$ & 0.20 & 0.04 & \\
\hline CA_C2809 & Predicted HD superfamily hydrolase & 0.14 & 0.02 & \\
\hline CA_C2810 & Possible glucoamylase (diverged), 15 family & 0.14 & 0.01 & \\
\hline CA_C2944 & $\begin{array}{l}\text { N-terminal domain intergin-like repeats and } \\
\text { c-terminal-cell wall-associated hydrolase } \\
\text { domain }\end{array}$ & 0.23 & 0.06 & $\mathrm{BuOH}$ \\
\hline CA_C3070 & Glycosyltransferase & 0.21 & 0.04 & \\
\hline CA_C3071 & Glycosyltransferase & 0.21 & 0.03 & \\
\hline CA_C3072 & Mannose-1-phosphate guanylyltransferase & 0.18 & 0.02 & \\
\hline CA_C3073 & $\begin{array}{l}\text { Sugar transferase involved in lipopolysaccha- } \\
\text { ride synthesis }\end{array}$ & 0.23 & 0.03 & \\
\hline CA_C3085 & $\begin{array}{l}\text { TPR-repeat-containing protein; Cell adhesion } \\
\text { domain }\end{array}$ & 0.25 & 0.12 & \\
\hline CA_C3086 & Protein containing cell adhesion domain & 0.20 & 0.11 & \\
\hline CA_C3251 & $\begin{array}{l}\text { Sensory transduction protein containing } \\
\text { HD_GYP domain }\end{array}$ & 0.20 & 0.11 & \\
\hline CA_C3264 & $\begin{array}{l}\text { Uncharacterized conserved protein, YTFJ } \\
\text { B.subtilis ortholog }\end{array}$ & 0.19 & 0.15 & $\mathrm{BuOH}$ \\
\hline CA_C3265 & Predicted membrane protein & 0.08 & 0.11 & \\
\hline CA_C3266 & Hypothetical protein & 0.07 & 0.07 & \\
\hline CA_C3267 & Specialized sigma subunit of RNA polymerase & 0.15 & 0.16 & \\
\hline CA_C3280 & $\begin{array}{l}\text { Possible surface protein, responsible for cell } \\
\text { interaction; contains cell adhesion domain } \\
\text { and ChW-repeats }\end{array}$ & 0.23 & 0.14 & \\
\hline CA_C3408 & $\begin{array}{l}\text { NADH oxidase (two distinct flavin oxidore- } \\
\text { ductase domains) }\end{array}$ & 0.03 & 0.02 & \\
\hline CA_C3409 & Transcriptional regulators, LysR family & 0.02 & 0.01 & \\
\hline CA_C3412 & $\begin{array}{l}\text { Predicted protein-S-isoprenylcysteine meth- } \\
\text { yltransferase }\end{array}$ & 0.22 & 0.06 & \\
\hline CA_C3422 & Sugar:proton symporter (possible xylulose) & 0.05 & 0.03 & \\
\hline CA_C3423 & $\begin{array}{l}\text { Acetyltransferase (ribosomal protein } \\
\text { N-acetylase subfamily) }\end{array}$ & 0.04 & 0.03 & \\
\hline CA_C3612 & Hypothetical protein & 0.18 & 0.00 & $\mathrm{BuOH}$ \\
\hline CA_P0053 & Xylanase, glycosyl hydrolase family 10 & 0.24 & 0.09 & $\mathrm{BuOH}$ \\
\hline CA_P0054 & Xylanase/chitin deacetylase family enzyme & 0.24 & 0.07 & $\mathrm{BuOH}$ \\
\hline CA_P0057 & Putative glycoprotein or S-layer protein & 0.21 & 0.13 & $\mathrm{BuOH}$ \\
\hline CA_P0135 & Oxidoreductase & 0.25 & 0.21 & \\
\hline CA_P0136 & AstB/chuR/nirj-related protein & 0.25 & 0.23 & \\
\hline CA_P0174 & Membrane protein & 0.25 & 0.14 & \\
\hline
\end{tabular}

${ }^{a}$ CymR indicates CymR regulon, BuOH indicates the genes to be down-regulated by butanol stress in an acidogenic chemostat in the study by Schwarz et al. [30] 
As expected based on the reduced consumption of glycerol (approximately one-fourth of the control strain) (Fig. 2) in $\triangle a d h E 2$, the gene cluster for glycerol transport and utilization (CA_C1319-CA_C1322) was downregulated ( $>4.3$-fold) under these conditions (Additional file 1: Table S7).

Most arginine biosynthesis-related genes known to respond negatively to butanol and butyrate stress [26] (i.e., CA_C0316 (argF/I), CA_C0973-CA_C0974 (argGH), CA_C2389-CA_C2388 $(\arg B D)$, CA_C2390-CA_C2391 $(\arg C)$, CA_C2644 (carB), and CA_C2645 (carA)) were significantly down-regulated ( $>4$-fold decrease) (Additional file 1: Table S7) in $\triangle a d h E 2$. As "alcohologenic cultures" of $\triangle a d h E 2$ produced $70 \mathrm{mM}$ of butyrate and no butanol (Fig. 2), this down-regulation is consistent with the high butyrate stress $(50 \mathrm{mM})$ response [26].

CA_C3486, which encodes a multimeric flavodoxin, was decreased by 4.4-fold in $\triangle a d h E 2$ (Additional file 1: Table S7), resulting in a loss of butanol production under alcohologenesis. This finding is consistent with the proposed hypothesis [12] that under alcohologenesis, the gene product of CA_C3486 may function as a redox partner between the hydrogenase and ferredoxin-NAD ${ }^{+}$ reductase and may participate in the redistribution of electron fluxes in favor of butanol formation.

\section{Conclusions}

The results presented here support the hypothesis of the roles of AdhE1 and AdhE2 in butanol formation, namely that AdhE1 is the key enzyme for butanol formation in solventogenesis and that AdhE2 is the key enzyme for butanol formation in alcohologenesis. Furthermore, this study also demonstrates the metabolic flexibility of $C$. acetobutylicum in response to genetic alteration of its primary metabolism.

\section{Methods}

\section{Bacterial strains and plasmid construction}

All $C$. acetobutylicum strains used in this study and in the control study were constructed from the $C$. acetobutylicum ATCC 824 $\triangle C A \_C 1502 \Delta u p p$ mutant strain, which was constructed for rapid gene knockout and gene knockin [38]. Detailed procedures, including all strains and primers used, are described in the online supporting information (Supplementary experimental procedures).

\section{Culture conditions}

All batch cultures were performed under strict anaerobic conditions in synthetic medium (MS), as previously described [4]. C. acetobutylicum was stored in spore form at $-20{ }^{\circ} \mathrm{C}$ after sporulation in MS medium. Heat shock was performed for spore germination by immersing the 30 - or $60-\mathrm{mL}$ bottle into a water bath at $80^{\circ} \mathrm{C}$ for $15 \mathrm{~min}$.
All the phosphate-limited continuous cultivations were performed as previously described by Vasconcelos et al. [4] and Girbal et al. [21] like in the control strain study [12]. The chemostat was fed a constant total of $995 \mathrm{mM}$ of carbon and maintained at a dilution rate of $0.05 \mathrm{~h}^{-1}$. The maintained $\mathrm{pH}$ of the bioreactor and the supplied carbon sources of each metabolic state were as follows: for acidogenesis, pH 6.3, with $995 \mathrm{mM}$ of carbon from glucose; for solventogenesis, $\mathrm{pH}$ 4.4, with $995 \mathrm{mM}$ of carbon from glucose; and for alcohologenesis, $\mathrm{pH}$ 6.3, with $498 \mathrm{mM}$ of carbon from glucose and $498 \mathrm{mM}$ of carbon from glycerol.

\section{RNA extraction and microarray}

Total RNA isolation and microarray experiments were performed as previously described [12]. Briefly, $3 \mathrm{~mL}$ of chemostat cultures was sampled, immediately frozen in liquid nitrogen and ground with 2-mercaptoethanol. RNA was extracted by using an RNeasy Midi kit (Qiagen, Courtaboeuf, France) and RNase-Free DNase Set (Qiagen) per the manufacturer's protocol. The RNA quantity and integrity were monitored using an Agilent 2100 Bioanalyzer (Agilent Technologies, Massy, France) and a NanoDrop ND-1000 spectrophotometer (Labtech France, Paris, France) at 260 and $280 \mathrm{~nm}$. All microarray procedures were performed per the manufacturer's protocol (Agilent One-Color Microarray-Based Exon Analysis).

\section{Analytical methods}

The optical density at $620 \mathrm{~nm}(\mathrm{OD} 620 \mathrm{~nm})$ was monitored and used to calculate the biomass concentration with the correlation factor between dry cell weight and OD620 nm (path length $1 \mathrm{~cm}$ ) of 0.28 , which was experimentally determined from continuous cultures and was used in a control strain study [12]. The glucose, glycerol, acetate, butyrate, lactate, pyruvate, acetoin, acetone, ethanol, and butanol concentrations were determined using high-performance liquid chromatography (HPLC), as described by Dusséaux et al. [39]. The concentration of the eluent $\mathrm{H}_{2} \mathrm{SO}_{4}$ was changed to $0.5 \mathrm{mM}$, as this concentration was required to optimize the mobile phase for the control strain study [12].

\section{Calculation of the cytosolic proteins concentration (protein molecules per cell)}

In a previously published work [12], we quantified the amount of (i) mRNA molecules per cell for all genes and (ii) protein molecules per cell (for approximately 700 cytosolic proteins) for steady-state chemostat cultures (at a specific growth rate of $0.05 \mathrm{~h}^{-1}$ ) of C. acetobutylicum under different physiological conditions. For $96 \%$ of the cytosolic proteins that could be quantified, a 
linear relationship was obtained, with an $\mathrm{R}^{2}>0.9$, when the numbers of protein molecules per cell were plotted against the numbers of mRNA molecules per cell. This result indicated that for steady-state continuous cultures run at the same specific growth rate and with the same total amount of carbon supplied, the rate of protein turnover is proportional to the mRNA content for $96 \%$ of the genes. As the mutants were cultivated in chemostat culture at the same growth rate $\left(0.05 \mathrm{~h}^{-1}\right)$, we used the absolute protein synthesis rates previously calculated [12] for each of the 700 genes to calculate the amount of protein molecule per cell for each of these 700 genes in the different mutants. (Additional file 2: Dataset S1).

\section{Calculation of the contribution of different enzymes on the butanol flux}

The contribution of the 5 proteins potentially involved in the butanol pathway, namely AdhE1, AdhE2, BdhA, $\mathrm{BdhB}$, and BdhC, was made as previously described [12] by assuming that all five enzymes function at their Vmax and using the calculated amount of each protein per cell (Additional file 2: Dataset S1).

\section{Additional files}

Additional file 1. Supplementary experimental procedures and results.

Additional file 2. Dataset S1. Transcriptomic data of the total open reading frames (ORFs).

\section{Abbreviations}

Flp: flippase; FRT: flippase recognition target; catP: chloramphenicol acetyltransferase.

\section{Authors' contributions}

CC, IMS, and PS conceived the study; MY performed all the experimental work. MY and PS performed the data analysis and drafted the manuscript. PS supervised the work. All authors read and approved the final manuscript.

\section{Author details}

${ }^{1}$ INSA, UPS, INP, LISBP, Université de Toulouse, Toulouse, France. ${ }^{2}$ INRA, UMR792, Toulouse, France. ${ }^{3}$ CNRS, UMR5504, Toulouse, France. ${ }^{4}$ Metabolic Explorer, Biopôle Clermont-Limagne, Saint Beauzire, France.

\section{Acknowledgements}

We thank Sophie Lamarre and Lidwine Trouilh for help with the data analysis.

\section{Availability of supporting data}

Microarray data can be accessed at GEO through accession number GSE69973

\section{Competing interests}

The authors declare that they have no competing interests.

\section{Consent for publication}

Not applicable.

Ethical Approval and Consent to participate

Not applicable.

\section{Funding}

This work was financially supported by the European Community's Seventh Framework Program "CLOSTNET" (PEOPLE-ITN-2008-237,942) to Minyeong Yoo.

Received: 4 February 2016 Accepted: 12 April 2016

Published online: 26 April 2016

\section{References}

1. Nair RV, Bennett GN, Papoutsakis ET. Molecular characterization of an aldehyde/alcohol dehydrogenase gene from Clostridium acetobutylicum ATCC 824. J Bacteriol. 1994;176(3):871-85.

2. Lutke-Eversloh T, Bahl H. Metabolic engineering of Clostridium acetobutylicum: recent advances to improve butanol production. Curr Opin Biotechnol. 2011;22(5):634-47.

3. Atsumi S, Liao JC. Metabolic engineering for advanced biofuels production from Escherichia coli. Curr Opin Biotechnol. 2008;19(5):414-9.

4. Vasconcelos I, Girbal L, Soucaille P. Regulation of carbon and electron flow in Clostridium acetobutylicum grown in chemostat culture at neutral pH on mixtures of glucose and glycerol. J Bacteriol. 1994;176(5):1443-50.

5. Girbal L, Vasconcelos I, Saint-Amans S, Soucaille P. How neutral red modified carbon and electron flow in Clostridium acetobutylicum grown in chemostat culture at neutral pH. FEMS Microbiol Rev. 1995;16(2):151-62.

6. Girbal L, Soucaille P. Regulation of Clostridium acetobutylicum metabolism as revealed by mixed-substrate steady-state continuous cultures: role of NADH/NAD ratio and ATP pool. J Bacteriol. 1994;176(21):6433-8.

7. Girbal L, Soucaille P. Regulation of solvent production in Clostridium acetobutylicum. Trends Biotechnol. 1998;16(1):11-6.

8. Bahl H, Andersch W, Gottschalk G. Continuous production of acetone and butanol by Clostridium acetobutylicum in a two-stage phosphate limited chemostat. Eur J Appl Microbiol Biotechnol. 1982;15(4):201-5.

9. Grimmler C, Janssen H, Krauße D, Fischer R-J, Bahl H, Dürre P, Liebl W, Ehrenreich A. Genome-wide gene expression analysis of the switch between acidogenesis and solventogenesis in continuous cultures of Clostridium acetobutylicum. J Mol Microbiol Biotechnol. 2011;20(1):1-15.

10. Peguin S, Soucaille P. Modulation of Carbon and Electron Flow in Clostridium acetobutylicum by Iron Limitation and Methyl Viologen Addition. Appl Environ Microbiol. 1995;61(1):403-5.

11. Fischer RJ, Helms J, Durre P. Cloning, sequencing, and molecular analysis of the sol operon of Clostridium acetobutylicum, a chromosomal locus involved in solventogenesis. J Bacteriol. 1993;175(21):6959-69.

12. Yoo M, Bestel-Corre G, Croux C, Riviere A, Meynial-Salles I, Soucaille P. A Quantitative System-Scale Characterization of the Metabolism of Clostridium acetobutylicum. MBio 2015, 6(6):e01808-01815.

13. Sauer U, Dürre P. Differential induction of genes related to solvent formation during the shift from acidogenesis to solventogenesis in continuous culture of Clostridium acetobutylicum. FEMS Microbiol Lett. 1995;125(1):115-20.

14. Fontaine L, Meynial-Salles I, Girbal L, Yang X, Croux C, Soucaille P. Molecular characterization and transcriptional analysis of adhE2, the gene encoding the NADH-dependent aldehyde/alcohol dehydrogenase responsible for butanol production in alcohologenic cultures of Clostridium acetobutylicum ATCC 824. J Bacteriol. 2002;184(3):821-30.

15. Leang C, Ueki T, Nevin KP, Lovley DR. A genetic system for Clostridium ljungdahlii: a chassis for autotrophic production of biocommodities and a model homoacetogen. Appl Environ Microbiol. 2013;79(4):1102-9.

16. Cooksley CM, Zhang Y, Wang H, Redl S, Winzer K, Minton NP. Targeted mutagenesis of the Clostridium acetobutylicum acetone-butanol-ethanol fermentation pathway. Metab Eng. 2012;14(6):630-41.

17. Heap JT, Pennington OJ, Cartman ST, Carter GP, Minton NP. The ClosTron: a universal gene knock-out system for the genus Clostridium. J Microbiol Methods. 2007;70(3):452-64.

18. Apfel H. Salmonella marker vaccine. In.: Google Patents; 2012

19. Waghmare SK, Caputo V, Radovic S, Bruschi CV. Specific targeted integration of kanamycin resistance-associated nonselectable DNA in the genome of the yeast Saccharomyces cerevisiae. Biotechniques 2003, 34(5):1024-1028, 1033. 
20. Storici F, Bruschi CV. Involvement of the inverted repeat of the yeast 2-micron plasmid in Flp site-specific and RAD52-dependent homologous recombination. Mol Gen Genet. 2000;263(1):81-9.

21. Girbal L, Croux C, Vasconcelos I, Soucaille P. Regulation of metabolic shifts in Clostridium acetobutylicum ATCC 824. FEMS Microbiol Rev. 1995;17(3):287-97.

22. Cornillot E, Nair RV, Papoutsakis ET, Soucaille P. The genes for butanol and acetone formation in Clostridium acetobutylicum ATCC 824 reside on a large plasmid whose loss leads to degeneration of the strain. J Bacteriol. 1997;179(17):5442-7.

23. Cornillot E, Soucaille P. Solvent-forming genes in clostridia. Nature. 1996;380(6574):489-489.

24. Atsumi S, Hanai T, Liao JC. Non-fermentative pathways for synthesis of branched-chain higher alcohols as biofuels. Nature. 2008;451(7174):86-9.

25. Lehmann D, Lutke-Eversloh T. Switching Clostridium acetobutylicum to an ethanol producer by disruption of the butyrate/butanol fermentative pathway. Metab Eng. 2011;13(5):464-73.

26. Wang Q, Venkataramanan KP, Huang H, Papoutsakis ET, Wu CH. Transcription factors and genetic circuits orchestrating the complex, multilayered response of Clostridium acetobutylicum to butanol and butyrate stress. BMC Syst Biol. 2013;7:120

27. Alsaker KV, Paredes C, Papoutsakis ET. Metabolite stress and tolerance in the production of biofuels and chemicals: gene-expression-based systems analysis of butanol, butyrate, and acetate stresses in the anaerobe Clostridium acetobutylicum. Biotechnol Bioeng. 2010;105(6):1131-47.

28. Honicke D, Lutke-Eversloh T, Liu Z, Lehmann D, Liebl W, Ehrenreich A. Chemostat cultivation and transcriptional analyses of Clostridium acetobutylicum mutants with defects in the acid and acetone biosynthetic pathways. Appl Microbiol Biotechnol. 2014;98(23):9777-94.

29. Hillmann F, Doring C, Riebe O, Ehrenreich A, Fischer RJ, Bahl H. The role of PerR in O2-affected gene expression of Clostridium acetobutylicum. J Bacteriol. 2009;191(19):6082-93.

30. Schwarz KM, Kuit W, Grimmler C, Ehrenreich A, Kengen SW. A transcriptional study of acidogenic chemostat cells of Clostridium acetobutylicum-Cellular behavior in adaptation to n-butanol. J Biotechnol. 2012;161(3):366-77.
31. Steiner E, Scott J, Minton NP, Winzer K. An agr quorum sensing system that regulates granulose formation and sporulation in Clostridium acetobutylicum. Appl Environ Microbiol. 2012;78(4):1113-22.

32. Alsaker KV, Papoutsakis ET. Transcriptional program of early sporulation and stationary-phase events in Clostridium acetobutylicum. J Bacteriol. 2005;187(20):7103-18.

33. Paredes CJ, Rigoutsos I, Papoutsakis ET. Transcriptional organization of the Clostridium acetobutylicum genome. Nucleic Acids Res. 2004;32(6):1973-81.

34. Liu D, Chen Y, Ding F, Guo T, Xie J, Zhuang W, Niu H, Shi X, Zhu C, Ying $H$. Simultaneous production of butanol and acetoin by metabolically engineered Clostridium acetobutylicum. Metab Eng. 2015;27:107-14

35. Tangney M, Mitchell WJ. Analysis of a catabolic operon for sucrose transport and metabolism in Clostridium acetobutylicum ATCC 824. J Mol Microbiol Biotechnol. 2000;2(1):71-80.

36. Servinsky MD, Kiel JT, Dupuy NF, Sund CJ. Transcriptional analysis of differential carbohydrate utilization by Clostridium acetobutylicum Microbiology. 2010;156(11):3478-91.

37. Fischer RJ, Oehmcke S, Meyer U, Mix M, Schwarz K, Fiedler T, Bahl H. Transcription of the pst operon of Clostridium acetobutylicum is dependent on phosphate concentration and pH. J Bacteriol. 2006;188(15):5469-78.

38. Croux C, Nguyen NPT, Lee J, Raynaud C, Saint-Prix F, Gonzalez-Pajuelo M, Meynial-Salles I, Soucaille P. Construction of a restriction-less, marker-less mutant useful for functional genomic and metabolic engineering of the biofuel producer Clostridium acetobutylicum. Biotechnol Biofuel. 2016;9:21.

39. Dusseaux S, Croux C, Soucaille P, Meynial-Salles I. Metabolic engineering of Clostridium acetobutylicum ATCC 824 for the high-yield production of a biofuel composed of an isopropanol/butanol/ethanol mixture. Metab Eng. 2013;18:1-8

\section{Submit your next manuscript to BioMed Central and we will help you at every step:}

- We accept pre-submission inquiries

- Our selector tool helps you to find the most relevant journal

- We provide round the clock customer support

- Convenient online submission

- Thorough peer review

- Inclusion in PubMed and all major indexing services

- Maximum visibility for your research

Submit your manuscript at www.biomedcentral.com/submit
O Biomed Central 